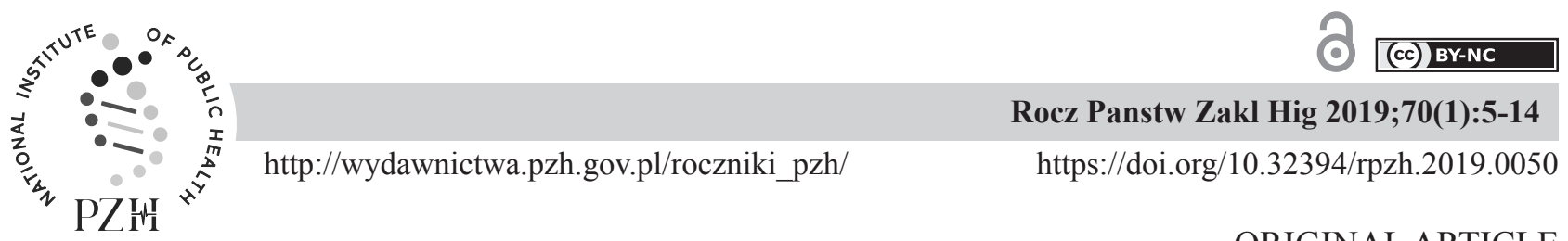

ORIGINAL ARTICLE

\title{
EXPOSURE ASSESSMENT OF INFANTS AND YOUNG CHILDREN ON SELECTED FUSARIUM TOXINS
}

\author{
Jacek Postupolski ${ }^{1}$, Andrzej Starski ${ }^{1}$, Ewa Ledzion ${ }^{1}$, Jolanta Kurpińska-Jaworska ${ }^{1}$, \\ Małgorzata Szczęsna
}

${ }^{1}$ National Institute of Public Health-National Institute of Hygiene, Department of Food Safety, Chocimska str. 24, Warsaw, Poland

\begin{abstract}
Background. Mycotoxins belong to substances harmful to human health. They are found mainly in cereal products and their preparations. In particular, infants and young children who consume cereal products, including porridge and gruel, are exposed to these substances.

Objective. The aim of the study is to assess the exposure of infants and young children in Poland to micotoxins (ochratoxin A. deoxynivalenol, nivalenol, fumonisins B1 and B1, T-2 and HT-2 toxins) derived from cereal products intended for infants and children.

Material and methods. Samples of products (302) were taken from all over the country in the following three years (2011, 2012 and 2013). HPLC-MS / MS method was used to determine the test compounds.

Results. Using the HPLC-MS / MS method, the assessment of population exposure in Poland to mikototoxins (ochratoxin A, deoxynivalenol, nivalenol, fumonisins B1 and B1, T-2 and HT-2 toxins) derived from cereal products (porridge, gruel) intended for infants and small children. Samples (302) were taken from across the country over the next three years. The exposure values obtained in the average exposure scenario range from 0.2 to $3 \%$ compared to the reference toxicological parameters. Considering that in the case of infants and young children, the tested products constitute a quantitatively significant part of the balanced diet of these consumers, and the remaining groups of foodstuffs, including vegetable products. fruit and meat and dairy products do not contribute significant amounts of mycotoxins to the diet can be accepted. that the level of contamination of cereal products does not pose a significant risk to the health of consumers. In the case of high exposure, it did not exceed $10 \%$ of the reference values for deoxynivalenol and the sum of fumonisins B1 and B2. These values were assessed as not relevant for the exposure of infants and young children. In contrast, in the case of zearalenone, the high level of exposure corresponded to $36 \%$ of the value of tolerable daily intake (TDI), and for the sum of T-2 and HT- 2 toxins, the value of $48 \%$ of tolerable daily intake. In both cases, the contribution of pollutants to the diet was significant, but still remained 2-3 times less than the tolerable daily intake. Given, that cereal products are the main source of these contaminants, it can be estimated that exceeding the TDI value in relation to the total diet of infants and young children is unlikely.

Conclusions. The exposure values obtained in the average exposure scenario range from 0.2 to $3 \%$ compared to the reference toxicological parameters. In the case of zearalenone, the high level of exposure corresponded to $36 \%$ of the TDI value. and for the sum of T-2 and HT-2 toxins, 48\% TDI. The contribution of pollutants to the diet in both cases was significant. however, it still remained 2-3 times less than the tolerable daily intake. Considering, that cereal products are the main source of these pollutants can be assessed. that exceeding the TDI value for the total diet of infants and young children is unlikely.
\end{abstract}

Key words: exposure assessment, mycotoxins, cereal products, products for infants and young children, TDI, tolerable daily intake,

\section{STRESZCZENIE}

Wprowadzenie. Mikotoksyny należą do substancji szkodliwych dla zdrowia ludzi. Wykazują właściwości mutagenne, kancerogenne, teratogenne i estrogenne. Stwierdzane są głównie w produktach zbożowych i ich przetworach. Na działanie tych substancji narażone są zwłaszcza niemowlęta i małe dzieci, które spożywają produkty zbożowe, w tym kaszki i kleiki. Cel. Celem pracy jest ocena narażenia niemowląt i małych dzieci w Polsce na mikotoksyny (ochratoksyna A, deoksyniwalenlol, niwalenol, fumonizyny B1 i B1, toksyny T-2 i HT-2) pochodzące z produktów zbożowych przeznaczonych dla niemowląt i dzieci.

Materiał i metody. Próbki produktów (302) były pobrane z terenu całego kraju w ciągu kolejnych trzech lat $(2011,2012$ i 2013). Do oznaczania badanych związków stosowano metodę HPLC-MS/MS.

Wyniki. Stosując metodę HPLC-MS/MS oceny narażenia populacji w Polsce na mikokotoksyny (ochratoksyna A, deoksyniwalen-

Corresponding author: Jacek Postupolski, National Institute of Public Health - National Institute of Hygiene, Department of Food Safety, Chocimska str. 24, 00-791 Warsaw, Poland, tel. +48 225421 314, e-mail: jpostupolski@pzh.gov.pl

(C) Copyright by the National Institute of Public Health - National Institute of Hygiene 
lol, niwalenol, fumonizyny B1 i B1, toksyny T-2 i HT-2) pochodzące z produktów zbożowych (kaszki, kleiki) przeznaczonych dla niemowląt i małych dzieci. Próbki (302) były pobrane z terenu całego kraju w ciągu kolejnych trzech lat. Uzyskane wartości narażenia w przypadku scenariusza przeciętnego narażenia wynoszą od 0.2 do $3 \%$ w porównaniu z referencyjnymi parametrami toksykometrycznymi. Biorąc pod uwagę, że w przypadku niemowląt i małych dzieci badane produkty stanowi istotną ilościowo część zrównoważonej diety tych konsumentów, a pozostałe grupy środków spożywczych w tym produkty warzywne. owocowe i mięsne oraz nabiał nie wnoszą istotnych udziałów mikotoksyn do diety można przyjąć. że poziom zanieczyszczenia produktów zbożowych nie stanowi istotnego ryzyka dla zdrowia konsumentów. W przypadku wysokiego narażenia nie przekraczało ono poziomu $10 \%$ wartości referencyjnych dla deoksyniwalenolu oraz sumy fumonizyn B1 i B2. Wartości te oceniono jako nie mające istotnego znaczenia dla narażenia niemowląt i małych dzieci. Natomiast w przypadku zearalenonu wysoki poziom narażenia odpowiadał 36\% wartości tolerowanego dziennego pobrania (TDI), a w przypadku sumy toksyn T-2 i HT-2 wartości 48\% tolerowanego dziennego pobrania. W obu przypadkach udział wnoszonego zanieczyszczenia do diety był znaczący, jednak nadal pozostawał 2-3 krotnie mniejszy niż tolerowane dzienne pobranie. Biorąc pod uwagę. że produkty zbożowe są głównym źródłem tych zanieczyszczeń można ocenić, że przekroczenie wartości TDI w odniesieniu do całkowitej diety niemowląt i małych dzieci jest mało prawdopodobne.

Wnioski. Uzyskane wartości narażenia w przypadku scenariusza przeciętnego narażenia wynoszą od 0.2 do $3 \% \mathrm{w}$ porównaniu z referencyjnymi parametrami toksykometrycznymi. W przypadku zearalenonu wysoki poziom narażenia odpowiadał 36\% wartości TDI, a w przypadku sumy toksyn T-2 i HT-2 wartości 48\% TDI. Udział wnoszonego zanieczyszczenia do diety w obu przypadkach był znaczący, jednak nadal pozostawał 2-3 krotnie mniejszy niż tolerowane dzienne pobranie. Biorąc pod uwagę, że produkty zbożowe są głównym źródłem tych zanieczyszczeń można ocenić, że przekroczenie wartości TDI w odniesieniu do całkowitej diety niemowląt i małych dzieci jest mało prawdopodobne.

Słowa kluczowe: ocena narażenia, mikotoksyny, produkty zbożowe, produkty dla niemowląt i małych dzieci, TDI, tolerowane dzienne pobranie

\section{INTRODUCTION}

Mycotoxins - secondary mould metabolites with undesirable effects for humans are common in the environment. Their presence is not related to the development of industry or transport. which in the common understanding are considered to be the main factors responsible for the occurrence of food contamination. These toxins are mainly produced by fungi of the genera Penicilium, Aspergillus and Fusarium. Their occurrence is associated with the inevitable presence of mould in the environment. Mycotoxins are present in agricultural products of basic importance for humans - in cereals (aflatoxins, ochratoxin A (OTA), Fusarium toxins and oilseeds (aflatoxins) and their preparations. They are also often detected in significant quantities in other foods - nuts, spices, dried fruit, coffee, wine, fruit preparations (aflatoxins, ochratoxin A, patulin). They may be present in raw materials of animal origin as a result of feeding with mycotoxin-contaminated feed. These substances are stable in most processes used in food processing, including at elevated temperatures. In many cases, they are characterized by significant acute toxicity, and they have carcinogenic, immunotoxic. nephro- and hepatotoxic effects.

In recent years, significant progress in food toxicology and the development of analytical techniques has caused attention to toxins produced by fungi of the genus Fusarium, widespread in the temperate climate zone, including in European agricultural areas. They are detected mainly in cereals and products obtained from them. The formation of Fusarium toxins occurs as a result of infection of plants (cereals) in the field, already during flowering. For this reason, their occurrence is dependent on climatic conditions during the growing season, rainfall and high humidity during the flowering of cereals are the cause of so-called "Fusarium years". There is then a particularly large toxin contamination. They constitute a large group of compounds with diversified chemical structure and a broad spectrum of toxic effects. To date, toxicological evaluation of the following Fusarium toxins: deoxynivalenol (DON), nivalenol (NIV), toxins T-2 and HT-2, zearalenone (ZAE) and fumonisins (FB) has been performed.

The increasing number of scientific publications on the contamination of foodstuffs with T-2 and HT-2 toxins, as well as the increasingly frequent detection of them in crops and food is noteworthy. In addition to the development of analytical methods, some authors explain this phenomenon in the recent decades of the effects of global warming. It is predicted that the temperature in the region of Central Europe may increase by 3 to $5^{\circ} \mathrm{C}$. This may cause the migration of some mold species to new regions, as well as create conditions for the production of mycotoxins by species previously considered non-toxic.

T-2 and HT-2 toxins are substances with hematotoxic. neurotoxic and immunotoxic effects. The European Commission indicates that there is a risk of exceeding the tolerable daily intake (TDI) for these toxins by a particularly vulnerable population group - infants and young children. Due to not fully developed detox mechanisms young children are particularly sensitive to xenobiotics. It is underlined that the estimation of sampling can be an error due to the use of analytical methods with too high detection limits (LOD). 
The project uses the method enabling the simultaneous determination of many mycotoxins. For the tests. in addition to the T-2 and HT-2 toxin. Deoxynivalenol, nivalenol and zearalenone were selected. DON and NIV were selected for evaluation due to the occurrence of reports of their occurrence independently of each other, whereas until now DON was considered to be an indicator mycotoxin. informing simultaneously about the presence of NIV. Zearalenone was indicated because of estrogenic activity, which is atypical for mycotoxins, especially harmful to small children's organisms, especially during the period of formation of reproductive organs.

Taking into account the above facts, it was considered advisable to estimate the exposure of infants and young children to T-2 and HT-2 toxins and to other indicated Fusarium toxins - dexinvalenol, nivalenol and zearalenone.

\section{MATERIAL AND METHODS}

\section{Samples}

Samples of grain products weighing not less than 1 $\mathrm{kg}$ were collected in accordance with the rules set out in the Commission Regulation (EC) No. 401/2006 [9] by inspectors of Sanitary and Epidemiological Stations. Samples were collected from retail sales throughout the country in 2011-2013 and sent to the Laboratory of the Food Safety Department of the National Institute of Public Health - National Institute of Hygiene. A total of 302 samples of products for infants and young children were delivered to the Laboratory.

\section{Methodology of determination}

A modified method of high performance liquid chromatography coupled with mass spectrometry (HPLC-MS/MS). developed by Sulyok et al. [11] was used to determine the level. Analytical grade reagents from Merck were used, with the exception of acetonitrile and ammonium acetate for mass spectrometry (Baker) and toxin standards, including those labelled with isotope (Biopure). The water was purified by reverse osmosis and demineralization.
A $4.0 \mathrm{~g}$ sample was weighed into a falcon tube with an accuracy of 0.01 g. $12 \mathrm{ml}$ extraction solution (80 parts acetonitrile, 1 part acetic acid, 19 parts water) was added and homogenized in an UltraTurax homogenizer for $3 \mathrm{~min}$. The homogenate was centrifuged for 20 $\min$ at $4000 \mathrm{x} g$. The $1 \mathrm{ml}$ extract was transferred to autosampler vials and an internal standard solution (U-[13C22] HT-2 toxin or verrucol) was added. For chromatographic analysis, a Water Alliance 2695 liquid chromatograph was used with a C18-AtlantisTM dC18 $3 \mu \mathrm{m} 100 \AA$. $2.1 \times 100 \mathrm{~mm}$ column Waters.

Chromatograph operating conditions:

\section{HPLC analysis}

The mobile phase flow $0.2 \mathrm{ml} / \mathrm{min}$

The composition of the mobile phase:

Phase A: $10 \%(\mathrm{~V} / \mathrm{V})$ aqueous solution of $5 \mathrm{mM}$ ammonium acetate and $1 \%$ acetic acid with $90 \%$ methanol

Phase B: $90 \%(\mathrm{~V} / \mathrm{V})$ aqueous solution of $5 \mathrm{mM}$ ammonium acetate and $1 \%$ acetic acid with $10 \%$ methanol.

Gradient profile:

$\begin{array}{ccc}\text { Time (min) } & \text { Phase A (\%) } & \text { Phase B (\%) } \\ 0-5 & 0 & 100 \\ 5-30 & 100 & 0 \\ 30-60 & 100 & 0 \\ 60-65 & 0 & 100 \\ 65-70 & 0 & 100\end{array}$

The dispensed volume - $20 \mu 1$

Column temperature $-40^{\circ} \mathrm{C}$

The temperature of the sampler $10^{\circ} \mathrm{C}$

\section{Calibration}

6 point calibration, points $1-5$ prepared by diluting the working solution for point 6. Concentrations according to the table below. Solvent mixture of chromatographic phases A and B $1+1(\mathrm{~V} / \mathrm{V})$. Working solution 6 prepared from stock solutions.

Phase A: $5 \mathrm{mM}$ AcoNH 4. 1\% (V/V) AcOH in a mixture of $100 \mathrm{ml}$ water $+900 \mathrm{ml}$ methanol.

Phase B: $5 \mathrm{mM}$ AcoNH 4. $1 \%(\mathrm{~V} / \mathrm{V}) \mathrm{AcOH}$ in a mixture of $900 \mathrm{ml}$ of water $+100 \mathrm{ml}$ of methanol.

Table 1. Concentration of standard solutions

\begin{tabular}{|c|c|c|c|c|c|c|}
\hline Mycotoxin & $\begin{array}{l}\text { Point } 1 \\
(\mathrm{ng} / \mathrm{ml})\end{array}$ & $\begin{array}{l}\text { Point } 2 \\
(\mathrm{ng} / \mathrm{ml})\end{array}$ & $\begin{array}{l}\text { Point } 3 \\
\text { (ng/ml) }\end{array}$ & $\begin{array}{l}\text { Point } 4 \\
\text { (ng/ml) }\end{array}$ & $\begin{array}{l}\text { Point } 5 \\
(\mathrm{ng} / \mathrm{ml})\end{array}$ & $\begin{array}{l}\text { Point } 6 \\
\text { (ng/ml) }\end{array}$ \\
\hline $\mathrm{DON}$ & 100 & 200 & 400 & 800 & 2000 & 4000 \\
\hline NIV & 100 & 200 & 400 & 800 & 2000 & 4000 \\
\hline ZEA & 10 & 20 & 40 & 80 & 200 & 400 \\
\hline OTA & 0.25 & 0.5 & 1 & 2 & 5 & 10 \\
\hline HT-2 & 7.5 & 15 & 30 & 60 & 150 & 300 \\
\hline $\mathrm{T}-2$ & 7.5 & 15 & 30 & 60 & 150 & 300 \\
\hline FB2 & 100 & 200 & 400 & 800 & 2000 & 4000 \\
\hline FB1 & 100 & 200 & 400 & 800 & 2000 & 4000 \\
\hline${ }^{13} \mathrm{C}-\mathrm{HT}-2$ & 15 & 15 & 15 & 15 & 15 & 15 \\
\hline
\end{tabular}




\section{Internal standard 13C-HT-2}

The table shows the results obtained for the internal standard signal. The 13C labeled standard was added directly to the sample dispensed to the LC/MS measuring system. Samples are understood as separate calibration solutions or further extracts. In samples containing the RSD matrix is greater (probable impact of the matrix), but between successive dosing from the same sample, the stretch marks do not differ significantly for the standards and real samples (indicates the precision of the instrumental measurement).

\section{Internal standard VER (verularol)}

$250 \mathrm{ng} / \mathrm{ml}$ based on the final solution dosed for measurement were used. For the assumed standard recovery of $100 \%$ (IS: VER/IS: 13C-HT-2). RRF 0.00397341 was obtained.
Preparation of validation samples. validation levels

$\mathrm{Up}$ to $25 \mathrm{~g}$ of wheat flour. an fortifying solution (6 calibration point) and $100 \mathrm{ml}$ extraction solvent were added. The sample was shaken vigorously for 90 minutes. Next, $2 \mathrm{ml}$ of extract (BLANK and LEVEL 1 samples) and $4 \mathrm{ml}$ (LEVEL 3 and LEVEL 2 samples) were taken. which was evaporated in a gentle stream of nitrogen at $45^{\circ} \mathrm{C}$, then the sample was dissolved in 400 $\mu \mathrm{l}$ of phase $\mathrm{A}$ and $\mathrm{B}$ mixtures $(1+1 \mathrm{~V} / \mathrm{V})$ was filtered through a syringe filter and $20 \mu \mathrm{l}$ of $13 \mathrm{C}-\mathrm{HT}-2$ internal standard solution was added. The prepared samples were dosed into the LC/MS measuring system. For the savings of standards one extract was used for each validation level. Enrichment levels are listed in Table 2.

Table 2. Working conditions of MS / MS mass spectrometer (Waters Quattro Micro API MRM mode. ES + ionization

\begin{tabular}{|c|c|c|c|c|}
\hline Toxin /IS & Parent ion $(\mathrm{m} / \mathrm{z})$ & Dauther ion potomny $(\mathrm{m} / \mathrm{z})$ & $\begin{array}{c}\text { Cone } \\
\text { voltage }\end{array}$ & $\begin{array}{c}\text { Collisieon } \\
\text { energy }\end{array}$ \\
\hline DON & 297.10 & 249.10 & 22 & 12 \\
\hline NIV & 313.10 & 125.00 & 24 & 12 \\
\hline ZEA & 319.20 & 301.00 & 21 & 10 \\
\hline OTA & 404.00 & 239.00 & 26 & 24 \\
\hline HT-2 & 442.2 & 263.20 & 18 & 13 \\
\hline HT-2 C13 (IS) & 464.3 & 278.1 & 20 & 14 \\
\hline $\mathrm{T}-2$ & 484.3 & 305.1 & 24 & 14 \\
\hline FB1 & 722.30 & 334.3 & 46 & 40 \\
\hline FB2 & 706.4 & 336.2 & 48 & 40 \\
\hline \multicolumn{5}{|c|}{ Source parametrs } \\
\hline Capillary & \multicolumn{4}{|c|}{$4.00 \mathrm{kV}$} \\
\hline Cone & \multicolumn{4}{|c|}{$20.00 \mathrm{~V}$} \\
\hline Extractor & \multicolumn{4}{|c|}{$2.00 \mathrm{~V}$} \\
\hline Temperature & \multicolumn{4}{|c|}{$100^{\circ} \mathrm{C}$} \\
\hline Evaporation temperature & \multicolumn{4}{|c|}{$350^{\circ} \mathrm{C}$} \\
\hline Gas flow on the cone (N2) & \multicolumn{4}{|c|}{$50 \mathrm{l} / \mathrm{h}$} \\
\hline Evaporative gas flow (N2) & \multicolumn{4}{|c|}{$500 \mathrm{l} / \mathrm{h}$} \\
\hline
\end{tabular}

\section{Exposure assessment for infants and young children}

The exposure assessment was performed taking into account the results obtained and various probable scenarios of consumption of cereal products intended for reconstitution for infants and young children. The obtained exposure values were compared with the reference values toxicological parameters - set by the European Food Safety Authority.

\section{Evaluation of consumption of cereal products tested} by infants and young children

In the case of consumption scenarios, i.e. the amount of consumption of cereal-based products for infants and young children, and intended for reconstitution with milk or water, multiple exposure scenarios can be considered.
Taking into account the guidelines for the diet of infants and young children, as well as suggestions of food producers associated with the consumption of the discussed products, two consumption variants were estimated. The first one refers to infants 12 months of age who have a body weight of $10 \mathrm{~kg}$, equivalent to around the 50th percentile of body weight for both girls and boys. The average consumption of foodstuffs tested is about $20 \mathrm{~g} /$ day, however, due to the diversity of products (ie. their purpose for reconstitution with water or milk), the content of flour and cereal ranges in the range of $50-100 \%$. The collection determined on this basis ranges from 1.0 to $2.0 \mathrm{~g} / \mathrm{kg}$ bw/day. The second variant is related to consumption by 3 -yearold children, whose body weight assume similar assumptions was estimated at $15 \mathrm{~kg}$, and consumption 
at the level of $60 \mathrm{~g} /$ day. Considering the adopted assumptions, the intake ranges from 1.5 to $4.0 \mathrm{~g} / \mathrm{kg}$ bw./ day. On the basis of this approach, the consumption of less than $1.0 \mathrm{~g} / \mathrm{kg} \mathrm{bw}$./day and high consumption at $4.0 \mathrm{~g} / \mathrm{kg} \mathrm{b.w./day} \mathrm{were} \mathrm{estimated.}$

Another important source of data on the consumption of the products in question by infants and young children is the database provided by EFSA. The results for the Polish population of young children $(n=$ 53) indicate consumption at the median level of $0.24 \mathrm{~g}$ $/ \mathrm{kg} \mathrm{bw} /$ day and at the 95th percentile level of $4.18 \mathrm{~g} /$ $\mathrm{kg}$ b.w./day. However, these studies took into account the consumption of all milling grain products, not only for feeding infants and young children.

Interesting insights are provided by German research and carried out in the United Kingdom. In the case of German studies carried out in the group of infants consuming foodstuffs produced with the participation of cereals, intended for reconstitution with water or milk (n = 140), the median value is $4.80 \mathrm{~g} / \mathrm{kg} \mathrm{bw} /$ day and the value $95 . /$ percentile $27.97 \mathrm{~g} / \mathrm{kg} \mathrm{mc} /$ day. In the case of young children $(\mathrm{n}=76)$ fed with similar preparations, the median value was $1.50 \mathrm{~g} / \mathrm{kg}$ bw / day while the 95th percentile value was $22.53 \mathrm{~g} / \mathrm{kg}$ bw / day. On the other hand, studies conducted in the United Kingdom on more numerous groups of consumers provide the following estimates of consumption: for infants $(\mathrm{n}=1070)$ median $1.11 \mathrm{~g} / \mathrm{kg}$ bw / day. 95th percentile $4.55 \mathrm{~g} / \mathrm{kg}$ bw /day and for young children $(\mathrm{n}=647)$ median $0.54 \mathrm{~g} / \mathrm{kg}$ bw / day and 95 th percentile $3.46 \mathrm{~g} / \mathrm{kg}$ bw / day. German research indicates a clearly higher consumption of the product group in question. Considering consumption clusters designated under the GEMS/WHO program, they may be more adequate for Poland than British studies. However, the estimation obtained in British studies is closer to the previously designated consumption based on nutritional guidelines given to consumers in Poland.

Table 4. Performance of analytical method

\begin{tabular}{|l|c|c|c|c|c|c|c|c|}
\hline \multicolumn{1}{|c|}{ Parameters } & DON & NIV & ZEA & OTA & HT-2 & T-2 & FB2 & FB1 \\
\hline Fortification level $(\mu \mathrm{g} / \mathrm{kg})$ & 100 & 100 & 10 & 0.25 & 7.5 & 7.5 & 100 & 100 \\
\hline Recovery $(\%)$ & 81.2 & 70.5 & 49.1 & 84.5 & 96.1 & 97.7 & 66.0 & 87.3 \\
\hline SD & 17.7 & 5.0 & 0.71 & 0.1099 & 1.20 & 0.47 & 5.4 & 6.0 \\
\hline RSD $(\%)$ & 5.1 & 7.1 & 14.4 & 65.1 & 14.3 & 6.5 & 6.0 & 5.7 \\
\hline Fortification level $(\mu \mathrm{g} / \mathrm{kg})$ & 200 & 200 & 20 & 0.5 & 15 & 15 & 200 & 200 \\
\hline Recovery $(\%)$ & 89.2 & 60.3 & 72.2 & 83.0 & 99.2 & 96.6 & 84.8 & 92.4 \\
\hline SD & 28.5 & 4.5 & 1.80 & 0.0897 & 1.08 & 1.18 & 7.7 & 9.5 \\
\hline RSD $(\%)$ & 6.4 & 3.8 & 12.5 & 14.5 & 6.8 & 8.2 & 4.0 & 4.7 \\
\hline Fortification level $(\mu \mathrm{g} / \mathrm{kg})$ & 400 & 400 & 40 & 1 & 30 & 30 & 400 & 400 \\
\hline Recovery $(\%)$ & 89.2 & 65.2 & 48.0 & 46.3 & 103.7 & 98.0 & 79.6 & 94.8 \\
\hline SD & 32.3 & 13.5 & 1.49 & 0.0849 & 1.31 & 1.77 & 18.9 & 19.8 \\
\hline RSD $(\%)$ & 5.2 & 5.2 & 7.8 & 12.7 & $4.0 \%$ & 6.0 & 5.5 & 5.0 \\
\hline
\end{tabular}

When analysing GEMS/WHO data on intake, Spanish studies should also be considered, due to the same nutritional cluster as Poland and Germany. In this case, the value of food intake for infants and young children produced on the basis of cereals was at the median level of $3.3741 \mathrm{~g} / \mathrm{kg}$ bw/day, while at the 95 th percentile $17.7303 \mathrm{~g} / \mathrm{kg}$ bw/day. The data on consumption compared are summarized in Table 3.

Table 3. Levels of fortification

\begin{tabular}{|l|c|c|c|c|}
\hline Level (ng/g) & Blank & Level 1 & Level 3 & Level 2 \\
\hline $\begin{array}{l}\text { DON, NIV, } \\
\text { FB1, FB-2 }\end{array}$ & 0 & 200 & 400 & 100 \\
\hline ZEA & 0 & 20 & 40 & 10 \\
\hline HT-2, T-2 & 0 & 15 & 30 & 7.5 \\
\hline OTA & 0 & 0.5 & 1 & 0.25 \\
\hline
\end{tabular}

The data on consumption discussed are very diverse. on their basis it is difficult to determine the intake value for the average and high consumption scenario, these values were proposed arbitrarily. In the case of average consumption, a value of $1.5 \mathrm{~g} / \mathrm{kg}$ bw / day was assumed, which corresponds to lower, but realistically estimated values, while for high consumption, a value close to extreme consumption, i.e. $20 \mathrm{~g} / \mathrm{kg}$ bw / day, was assumed to reflect the specific situations of consumer exposure.

\section{RESULTS}

The results of nd (not detected) were rejected in the performed statistical parameters. For comparison, results were also obtained using an internal standard added to the sample before preparation(VER verularol), the use of this standard may allow elimination of extraction errors. No verularol was introduced into the blank sample, the average recovery value for verularol obtained for the LEVEL 1 sample was $107.375 \%$. The results are shown in Table 4. 
The BLANK sample contains DON and fumonisins B1 and B2 at a low level. The presence of OTA and HT-2 is at the noise level. The recovery results obtained in recalcurrol are generally lower by 3.9-6.3\%. however, this is not a significant difference. RSD values are slightly higher (on average by $1.2 \%$ ) while the maximum ranges between samples in a few cases significantly increased (NIV, HT-2. FB2). a clearly better result was obtained for DON.

The use of verularol as a reference internal standard does not bring about a significant improvement in recoveries. As it also does not bring about a significant improvement in recoveries, in this case the results are on the verge of acceptability, (repeating).

Estimation of LOD and LOQ values. The values estimated are analysed by the signal-to-noise ratio $\operatorname{LOD}(\mathrm{s} / \mathrm{n})=3-\operatorname{LOQ}(\mathrm{s} / \mathrm{n})=9$; values are given in Table 5.
Table 5. Method performance parameters; detection limits (LOD) and quantification limits (LOQ)

\begin{tabular}{|l|c|c|c|c|}
\hline \multirow{2}{*}{ Mikotoxine } & \multicolumn{2}{|c|}{$\mathrm{LOD}(3 \times \mathrm{S} / \mathrm{N})$} & \multicolumn{2}{c|}{ LOQ $(10 \times \mathrm{S} / \mathrm{N})$} \\
\cline { 2 - 5 } & $\mathrm{ng} / \mathrm{ml}$ & $\mathrm{ng} / \mathrm{g}$ & $\mathrm{ng} / \mathrm{ml}$ & $\mathrm{ng} / \mathrm{g}$ \\
\hline DON & 5.0 & 2.0 & 16.3 & 6.5 \\
\hline NIV & 46.5 & 18.6 & 154.8 & 61.9 \\
\hline ZEA & 15.3 & 6.1 & 51.3 & 20.5 \\
\hline OTA & 0.18 & 0.07 & 0.60 & 0.24 \\
\hline HT-2 & 2.8 & 1.1 & 9.3 & 3.7 \\
\hline T-2 & 0.3 & 0.1 & 0.8 & 0.3 \\
\hline FB2 & 3.5 & 1.4 & 1.0 & 0.4 \\
\hline FB1 & 1.3 & 0.5 & 3.8 & 1.5 \\
\hline
\end{tabular}

The developed method of determination of Fusarium toxins in cereal products using HPLCMS/MS meets the requirements for methods used in official control; the obtained efficacy parameters are given in the Table 6.

Table 6. Results of Fusarium toxin determination in products for infants and young children

\begin{tabular}{|c|c|c|c|c|c|c|c|c|c|c|c|c|c|c|}
\hline \multirow[b]{2}{*}{ Micotoxine } & \multicolumn{3}{|c|}{ Samples } & \multicolumn{2}{|c|}{ Values } & \multicolumn{4}{|c|}{ Average } & \multirow[b]{2}{*}{ Mediane } & \multirow[b]{2}{*}{ P75 } & \multirow[b]{2}{*}{ P90 } & \multirow[b]{2}{*}{ P95 } & \multirow[b]{2}{*}{ Max } \\
\hline & $\mathrm{n}$ & $>$ LOQ & $\begin{array}{c}>\text { LOD \& } \\
<\text { LOQ }\end{array}$ & LOD & LOQ & LB & MB & UB & $>$ LOD & & & & & \\
\hline DON & 302 & 19 & 17 & 2 & 4 & 0.560 & 2.321 & 4.127 & 4.697 & 0 & 0 & 2.919 & 4.474 & 9.609 \\
\hline NIV & 302 & 3 & 3 & 2 & 4 & 0.136 & 2.096 & 4.068 & 6.851 & 0 & 0 & 0 & 0 & 14.247 \\
\hline ZEA & 302 & 14 & 14 & 1.8 & 3.6 & 0.435 & 2.069 & 3.758 & 4.697 & 0 & 0 & 0 & 3.589 & 19.660 \\
\hline OTA & 302 & 7 & 4 & 0.07 & 0.14 & 0.007 & 0.075 & 0.143 & 0.196 & 0 & 0 & 0 & 0 & 0.386 \\
\hline FB1 & 302 & 363 & 0 & 0.5 & 1 & 0.560 & 1.000 & 1.441 & 4.697 & 0 & 0 & 2.919 & 4.474 & 9.609 \\
\hline FB2 & 302 & 1 & 1 & 1.4 & 2.8 & 0.033 & 1.414 & 2.800 & 2.455 & 0 & 0 & 0 & 0 & 2.807 \\
\hline HT-2 & 302 & 0 & 3 & 1.1 & 2.2 & 0.013 & 1.102 & 2.200 & 1.279 & 0 & 0 & 0 & 0 & 1.549 \\
\hline $\mathrm{T}-2$ & 302 & 202 & 4 & 0.1 & 0.2 & 0.021 & 0.112 & 0.204 & 0.244 & 0 & 0 & 0 & 0.214 & 0.484 \\
\hline
\end{tabular}

Obtained results of determination of Fusarium toxins in products for children and infants are given in the Table 7.

Table 7. The number of tested samples in which mycotoxins were found

\begin{tabular}{|c|c|}
\hline Number of mycotoxins found & $\begin{array}{c}\text { Number of samples } \\
\text { (percentage of samples) }\end{array}$ \\
\hline 0 & $247(81.8 \%)$ \\
\hline 1 & $14(4.6 \%)$ \\
\hline 2 & $9(3.0 \%)$ \\
\hline 3 & $18(6.0 \%)$ \\
\hline 4 & $8(2.6 \%)$ \\
\hline 5 & $4(1.3 \%)$ \\
\hline 6 & $2(0.7 \%)$ \\
\hline 7 & 0 \\
\hline 8 & 0 \\
\hline Total number of positive results & $150(6.2 \%)$ \\
\hline Total number of tested samples & 302 \\
\hline $\begin{array}{c}\text { Total number of samples } \\
\text { in which at least } 1 \text { mycotoxin } \\
\text { was found }\end{array}$ & $55(18.2 \%)$ \\
\hline
\end{tabular}

Obtained results of determination of toxins, corrected for recovery, are presented in the Table 6 . It should be noted that in any sample no exceedance of the maximum allowable contamination established in the Commission Regulation (EC) No. 1881/2006, as amended. The number of samples in which at least one mycotoxin was found was $55(18.2 \%)$. Detailed information on the distribution of individual mycotoxins is given in the table Table 8 .

Exposure to the examined mycotoxins in no case exceeds the TDI value, also the maximum values do not exceed this parameter. It should be emphasized that for one sample. the level of contamination with zearalenone indicated about $50 \%$ of the value of tolerable daily intake. Detailed results are included in Table 9. 
Table 8. Sample data on the consumption of food produced with cereals for infants and young children

\begin{tabular}{|c|c|c|c|c|c|c|c|c|}
\hline & \multirow{2}{*}{\multicolumn{2}{|c|}{ Own estimation }} & \multirow{3}{*}{$\begin{array}{c}\begin{array}{c}\text { EFSA database } \\
\text { (data for Poland) }\end{array} \\
\mathrm{n}=53 \\
\begin{array}{c}\text { young } \\
\text { children }\end{array} \\
\end{array}$} & \multicolumn{2}{|c|}{$\begin{array}{c}\text { EFSA database } \\
\text { (data for Germany) }\end{array}$} & \multicolumn{2}{|c|}{$\begin{array}{c}\text { EFSA database } \\
\text { ( British data) }\end{array}$} & \multirow{2}{*}{$\begin{array}{c}\begin{array}{c}\text { GEMS/ WHO } \\
\text { (data for Spain) }\end{array} \\
n=8\end{array}$} \\
\hline & & & & $\mathrm{n}=140$ & $\mathrm{n}=76$ & $\mathrm{n}=1070$ & $\mathrm{n}=647$ & \\
\hline Consumer group & infants & $\begin{array}{c}\text { young } \\
\text { children }\end{array}$ & & infants & $\begin{array}{l}\text { young } \\
\text { children }\end{array}$ & infants & $\begin{array}{c}\text { young } \\
\text { children }\end{array}$ & $\begin{array}{l}\text { young } \\
\text { children }\end{array}$ \\
\hline \multicolumn{9}{|c|}{ Level of consumption (g/kg bw/day) } \\
\hline Average & 1 & 1.5 & 0.24 & 4.80 & 1.5 & 1.11 & 0.54 & 3.3741 \\
\hline High & 2 & 4 & 4.18 & 27.97 & 22.53 & 4.55 & 3.46 & 17.7303 \\
\hline
\end{tabular}

Table 9. Estimation of the exposure value of infants and young children to mycotoxins from food cereals products intended for infants and young children. Comparison of the exposure in relation to the toxicological reference values

\begin{tabular}{|c|c|c|c|c|c|c|}
\hline \multirow[t]{2}{*}{ Mycotoxin } & \multirow{2}{*}{$\begin{array}{l}\text { Exposure } \\
\text { scenario }\end{array}$} & $\begin{array}{c}\text { Level of } \\
\text { contamination }\end{array}$ & Intake & Exposure & \multirow[t]{2}{*}{ Reference value } & \multirow{2}{*}{$\begin{array}{l}\text { Exposure value } \\
\text { in relation to the } \\
\text { reference value }\end{array}$} \\
\hline & & $\mu g / k g$ & $g / k g b w$. & $n g / k g b w$ & & \\
\hline \multirow{2}{*}{ Deoksyniwlaenol } & average & 2.321 & 1.5 & 3.5 & \multirow{2}{*}{$1 \mu \mathrm{g} / \mathrm{kg}$ b.w. (TDI) } & $0.4 \%$ \\
\hline & high & 4.474 & 20 & 89.5 & & $9 \%$ \\
\hline Nivalenol (NIV) & average & 2.096 & 1.5 & 3.1 & $0.7 \mu \mathrm{g} / \mathrm{kg}$ b.w. (PTDI) & $0.4 \%$ \\
\hline \multirow{2}{*}{ Zearalenone (ZAE) } & average & 2.069 & 1.5 & 3.1 & \multirow{2}{*}{$0.2 \mu \mathrm{g} / \mathrm{kg} \mathrm{b}$ w. (TDI) } & $1.6 \%$ \\
\hline & high & 3.589 & 20 & 71.8 & & $36 \%$ \\
\hline Ochratoxin A & average & 0.075 & 1.5 & $0.11(0.77 /$ week $)$ & 120 ng/kg b.w. (TWI) & $0.6 \%$ \\
\hline \multirow{2}{*}{ Sum of FB1+FB2 } & average & 2.414 & 1.5 & 3.6 & \multirow{2}{*}{$2 \mu \mathrm{g} / \mathrm{kg}$ b.w. (PTDI) } & $0.2 \%$ \\
\hline & high & 4.474 & 20 & 89.5 & & $4.5 \%$ \\
\hline \multirow{2}{*}{ Sum of T-2 + HT-2 } & average & 1.214 & 1.5 & 1.82 & \multirow{2}{*}{$0.1 \mu \mathrm{g} / \mathrm{kg}$ b.w. (TDI) } & $1.8 \%$ \\
\hline & high & 2.404 & 20 & 48.1 & & $48.1 \%$ \\
\hline
\end{tabular}

\section{DISCUSSION}

\section{Mycotoxins in the tested products}

Analysis of the obtained results of the content of individual mycotoxins in foodstuffs allows the adoption of two levels of contamination for risk assessment purposes - the level of average and high contamination In the first case, a value was looked for reflecting the average level of contamination of products. Due to the significant number of samples below the limit of quantification, the mean value determined as medium bound was taken as the average exposure value, ie. the average calculated assuming that for values below the limit of quantification the half-valued limit value is taken to determine the average, which in this work is tantamount to accepting the limit of detection. At the same time, it should be noted that there are significant differences between mean values calculated as lower bound, i.e. assuming that if a result is below the limit of quantification, the averaged values are calculated and calculated as upper bound, i.e. assuming a value equal to the limit of quantification. A large discrepancy between the estimated values indicates a significant uncertainty of estimation at the level of average pollution. In the second approach. the 95th percentile of the occurrence of mycotoxins in the tested products was used to determine the high level of pollution. In the case of T-2 and HT-2 toxins, the mean upper bound value was assumed.

Obtained results do not allow for exposure assessment in the case of high levels of contamination with nivalenol and ochratoxin A - the 95th percentile is zero, which indicates incidental high levels of these mycotoxins. Due to the similar toxic effects and the determination of group toxicological parameters by EFSA. the exposure assessment was carried out for the sum of the occurrence of some mycotoxins. Taking into account the above assumptions. the exposure assessment was performed for both levels of contamination in the case of deoxynivalenol, zearalenone, sum of fumines B1 and B2 and sum of T- 2 and HT-2 toxins, while for nivalenol and ochratoxin A the exposure assessment was limited to the average.

\section{Evaluation of consumption of cereal products by infants and young children}

In the case of consumption scenarios, i.e. the amount of consumption of cereal-based products for infants and young children, and intended for reconstitution with milk or water, multiple exposure scenarios can be considered.

Taking into account the guidelines for the diet of infants and young children, as well as suggestions of food producers associated with the consumption of the discussed products, two consumption variants were estimated. The first one refers to infants 12 months of age who have a body weight of $10 \mathrm{~kg}$, equivalent to around the 50th percentile of body weight for both girls and boys. The average consumption of foodstuffs tested is about $20 \mathrm{~g}$ / day, however, due to the diversity of products (ie. their purpose for reconstitution with water or milk), 
the content of flour and cereal ranges in the range of 50$100 \%$. The collection determined on this basis ranges from 1.0 to $2.0 \mathrm{~g} / \mathrm{kg}$ bw/day. The second variant is related to consumption by 3-year-old children, whose body weight assume similar assumptions was estimated at $15 \mathrm{~kg}$, and consumption at the level of $60 \mathrm{~g} /$ day. Considering the adopted assumptions, the intake ranges from 1.5 to $4.0 \mathrm{~g} / \mathrm{kg} \mathrm{bw} /$ day. On the basis of this approach, the consumption of less than $1.0 \mathrm{~g} / \mathrm{kg}$ bw./day and high consumption at $4.0 \mathrm{~g} / \mathrm{kg}$ bw/day were estimated.

Another important source of data on the consumption of the products in question by infants and young children is the database provided by EFSA. The results for the Polish population of young children $(\mathrm{n}=53)$ indicate consumption at the median level of $0.24 \mathrm{~g} / \mathrm{kg}$ bw/day and at the 95th percentile level of $4.18 \mathrm{~g} / \mathrm{kg}$ bw/day. However, these studies took into account the consumption of all milling grain products, not only for feeding infants and young children.

Interesting insights are provided by German research and carried out in the United Kingdom. In the case of German studies carried out in the group of infants consuming foodstuffs produced with the participation of cereals, intended for reconstitution with water or milk ( $\mathrm{n}=140)$, the median value is $4.80 \mathrm{~g} / \mathrm{kg}$ bw / day and the value 95 th percentile $27.97 \mathrm{~g} / \mathrm{kg}$ bw / day. In the case of young children $(n=76)$ fed with similar preparations, the median value was $1.50 \mathrm{~g} / \mathrm{kg}$ bw/ day while the 95th percentile value was $22.53 \mathrm{~g} / \mathrm{kg}$ bw/ day. On the other hand, studies conducted in the United Kingdom on more numerous groups of consumers provide the following estimates of consumption: for infants $(\mathrm{n}=1070)$ median $1.11 \mathrm{~g} / \mathrm{kg}$ bw / day. 95th percentile $4.55 \mathrm{~g} / \mathrm{kg}$ bw / day and for young children $(\mathrm{n}=647)$ median $0.54 \mathrm{~g} / \mathrm{kg}$ bw / day and 95th percentile $3.46 \mathrm{~g} / \mathrm{kg}$ bw / day. German research indicates a clearly higher consumption of the product group in question. Considering consumption clusters designated under the GEMS/WHO program, they may be more adequate for Poland than British studies. However, the estimation obtained in British studies is closer to the previously designated consumption based on nutritional guidelines given to consumers in Poland.

When analysing GEMS/WHO data on intake, Spanish studies should also be considered, due to the same nutritional cluster as Poland and Germany. In this case, the value of food intake for infants and young children produced on the basis of cereals was at the median level of $3.3741 \mathrm{~g} / \mathrm{kg}$ bw/day. while at the 95 th percentile $17.7303 \mathrm{~g} / \mathrm{kg}$ bw/day. The data on consumption compared are summarized in Table 8 .

The data on consumption discussed are very diverse. on their basis it is difficult to determine the intake value for the average and high consumption scenario, these values were proposed arbitrarily. In the case of average consumption. a value of $1.5 \mathrm{~g} / \mathrm{kg}$ bw / day was assumed, which corresponds to lower, but realistically estimated values, while for high consumption, a value close to extreme consumption, ie. $20 \mathrm{~g} / \mathrm{kg}$ bw / day, was assumed to reflect the specific situations of consumer exposure.

\section{Exposure estimation}

Given the data on the occurrence of mycotoxins and the consumption of the product group in question, consumer exposure was assessed and comparisons were made with the toxicological reference values estimated by EFSA. Two exposure scenarios were selected: the first corresponding to the average medium bound and the average consumption, and the second corresponding to the high pollution (95th percentile) and high consumption. The results are summarized in table 9.

As reference parameters, TDI values were used, i.e. a tolerable daily intake, in some cases temporarily determined, designated as PTDI. For ochratoxin A, reference was made to the TWI value, i.e. the tolerable weekly intake - in this case, the daily intake was multiplied and the percentage was taken throughout the week. The exposure values obtained in the average exposure scenario range from 0.2 to $3 \%$ compared to the reference toxicological parameters. Considering that the product group in question in the case of infants and young children is a quantitatively part of the balanced diet of these consumers, and other food groups including vegetable, fruit and meat products and dairy products do not contribute significant mycotoxin content to the diet, it can be assumed that contamination of cereal products does not pose a significant risk to the health of consumers.

In the case of high exposure, it did not exceed 10\% of the reference values for deoxynivalenol and the sum of fumonisins B1 and B2, these values were assessed as not relevant for the exposure of infants and young children. In contrast, in the case of zearalenone, the high level of exposure corresponded to $36 \%$ of the value of tolerable daily intake. and for the sum of T-2 and HT-2 toxins, the value of $48 \%$ of tolerable daily intake. In both cases, the contribution of pollutants to the diet was significant. but still remained 2-3 times less than the tolerable daily intake. Considering that cereal products are the main source of these contaminants, it can be estimated that exceeding the TDI value in relation to the total diet of infants and young children is unlikely.

The contamination levels obtained for the tested products are similar to those from other European countries. Obtained data indicate that the values of tolerable daily intake for tested toxins are not exceeded, however, it should be emphasized that the formation of Fusarium toxins depends on weather conditions and levels of contamination in years with unfavourable climatic conditions can be many times higher. 


\section{CONCLUSIONS}

1. The developed method for the determination of mycotoxins in cereal products using HPLCMS/MS meets the requirements of the methods used in official control in terms of the limit of quantification, precision, recovery and uncertainty of the result.

2. The obtained data indicate that the values of tolerable daily intake for the tested toxins are not exceeded, however, it should be emphasized that the formation of Fusarium toxins depends on weather conditions and levels of pollution in years with unfavourable climatic conditions can be many times higher.

3. It is advisable to continue monitoring studies in this area, expanding them with new product groups, especially for infants and young children.

\section{Acknowledgements}

This study was financially supported by the National Science Centre in Poland within the research project No N N404 110139.

\section{Conflict of interest}

The authors declare no conflict of interest.

\section{REFERENCES}

1. Dietary intake by the population of EU Member States. SCOOP task 3.2.10 2003.

2. GEMS/Food regional diets: regional per capita consumption of raw and semi-processed agricultural commodities, prepared by the Global Environment Monitoring System/Food Contamination Monitoring and Assessment Programme. WHO. 2006. http://www.who. int/foodsafety/chem/gems_regional_diet.pdf.

3. IARC. Monographs on the evaluation of carcinogenic risks to humans; Vol. 56: Some naturally occurring substances, food items and constituents heterocyclic aromatic amines and mycotoxins. International Agency for Research on Cancer. World Health Organization. 1993, 397-433; Lyon.

4. Krska R., Molinelli I.: Mycotoxin analysis: stateof-the-art and future trends. Bioanal Chem. Anal. 2007;387:145-148.

5. Magan N., Aldred D.: Post-harvest control strategies: Minimizing mycotoxins in the food chain. Int. J of Food Microbiology. 2007;119:131-139.

6. Miraglia M., Marvin H.J, Kleter G.A, Battilani P., Brera C., Coni E., Cubadda F., Croci L., De Santis B., Dekkers S., Filippi L., Hutjes R.W., Noordam M.Y,. Pisante M., Piva G., Prandini A, Toti L, van den Born G.J., Vespermann A.: Climate change and food safety: An emerging issue with special focus on Europe. Food Chem Toxicol 2009;47:1009-1021.

7. Morgavi D.P., Riley R.T.: An historical overview of field disease outbreaks known or suspected to be caused by consumption of feeds contaminated with Fusarium toxins. Animal Feed Science and Technology. 2007;137:201-212.

8. Mossa M., Thrane U.: Fusarium taxonomy with relation to trichothecene formation. Toxicology Letters 2004;153:23-28.

9. Opinion of the Scientific Committee on Food on Fusarium Toxins Part 1: Deoxynivalenol (DON) adopted on $22 \mathrm{JUNE} 000 \mathrm{SCF} / \mathrm{CS} / \mathrm{CNTM} / \mathrm{MYC} / 22 \mathrm{Rev} 3$ final

10. Opinion of the Scientific Committee on Food on Fusarium Toxins Part 2: Zearalenone (ZEA) adopted on 22 JUNE 000SCF/CS/CNTM/MYC/22 Rev. 3 final

11. Opinion of the Scientific Committee on Food on Fusarium toxins. Part 4: Nivalenol, expressed on 19 October 2000. Scientific Committee on Food. 2000: SCF/CS/ $\mathrm{CNTM} / \mathrm{MYC} / 26$ Final.

12. Opinion of the Scientific Committee on Food on Fusarium toxins. Part 6: Group evaluation of T-2 toxin, HT-2 toxin, nivalenol and deoxynivalenol, adopted on 26 February 2002. Scientific Committee on Food. 2002: SCF/CS/CNTM/MYC/27 Final.

13. Opinion of the Scientific Committee on Food on Fusarium toxins. Part 5: T-2 toxin and HT-2 toxin, adopted on 30 May 2001. Scientific Committee on Food. 2001: SCF/CS/CNTM/MYC/25 Rev 6 Final.

14. Pasquali M., Giraud F., Brochot C., Cocco E., Hoffman L., Bohn T.: Genetic Fusarium chemotyping as a useful tool for predicting nivalenol contamination in winter wheat. Int. J. of Food Microbiology. 2010;137:246-253; https://doi.org/10.1016/j.ijfoodmicro.2009.11.009

15. Postupolski J., Rybińska K., Ledzion E., KurpińskaJaworska J., Szczęsna M., Karłowski K.: Badania monitoringowe w zakresie oznaczania poziomu toksyn T-2 i HT-2 w przetworach zbożowych.[Monitoring programme of T-2 and HT-2 toxins level in cereal products]. Rocz Panstw Zakl Hig 2008;59(4):429-35.

16. Commission Regulation (EC) No 1881/2006 of 19 December 2006 setting maximum levels for certain contaminants in foodstuffs IJ EU. UE 2006. L 364. 5-24 (consolidated version)

17. Commission Regulation (EC) No 401/2006 of 23 February 2006 laying down the methods of sampling and analysis for the official control of the levels of mycotoxins in foodstuffs. OJ UE. 2006. L 70. 12-34.

18. Russell M., Paterson M., Lima N.: How will climate change affect mycotoxins in food? Food Research International. 2010;43:1902-1914.

19. Rybińska K.,Postupolski J., Ledzion E., KurpińskaJaworska J.. Szczęsna M.: Programy monitoringowe realizowane przez Państwową Inspekcję Sanitarną w zakresie zanieczyszczenia wybranych środków spożywczych mikotoksynami. [Monitoring programs realized by the State Sanitary Inspection concerning the contamination of selected foodstuffs by mycotoxins]. Rocz Panstw Zakl Hig. 2008;59(1):1-7.

20. Schrödter $R$ : Influence of harvest and storage conditions on trichothecenes levels in various cereals. Toxicology Letters 2004;153:47-49.

21. Sulyok M. R., Krska R., Schuhmacher R.: A liquid chromatography/tandem mass spectrometric multi-mycotoxin method for the quantification of 87 analytes and 
its application to semi-quantitative screening of moldy food samples. Anal Bioanal Chem. 2007;389:1505-23.

22. Thrane U., Adler A., Clasen P.E., Galvano F., Langseth W., Lew H., Logrieco A., Nielsen K.F., Ritieni A.: Diversity in metabolite production by Fusarium langsethiae. Fusarium poae, and Fusarium sporotrichioides. Int. J. Food Microbiol. 2004;95:257-266.

23. Tritscher A.. Page S.: The risk assessment paradigm and its application for trichothecenes Toxicology Letters. 2004;153:155-163.

24. Usleber E.: Improvement and Validation of Methods of Analysis for Type A Trichothecenes (T-2 Toxin and HT-2 Toxin) and Occurrence of these Mycotoxins in Foods in Germany. Fifth Fusarium Toxin Forum. Brussels, January 2008.

25. Juan C., Raiola A., Mañes J., Ritieni A.: Presence of mycotoxin in commercial infant formulas and baby foods from Italian market. Food Control.2014;39:227-236. http://doi.org/https://doi.org/10.1016/j.foodcont.2013.10.036

26. Rubert J., Soler C., Mañes J.: Application of an HPLCMS/MS method for mycotoxin analysis in commercial baby foods. Food Chemistry. 2012;133:176-183 http:// doi.org/10.1016/j.foodchem.2011.12.0355

27. Selvaraj J. N., Wang Y., Zhou L., Zhao Y., Xing F., Dai $X .$, Liu Y.: Recent mycotoxin survey data and advanced mycotoxin detection techniques reported from China: a review. Food Additives and Contaminants - Part A Chemistry. Analysis, Control. Exposure and Risk Assessment 2015. https://doi.org/10.1080/19440049.2015 .1010185

Received: 26.05 .2016

Revised: 26.10.2018

Accepted: 28.01.2019 